\title{
Grief And Resilience - Parents Who Lost Young Adult Children
}

\author{
Rejane Dutra Bergamaschi \\ Post Graduate Program in Environment and Health \\ Universidade do Planalto Catarinense \\ Av. Marechal Castelo Branco \\ 170. Lages. Santa Catarina \\ Brazil \\ Anelise Viapiana Masiero \\ Post-Graduate Program in Environment and Health \\ Universidade do Planalto Catarinense \\ Av. Marechal Castelo Branco, 170 \\ Lages. Santa Catarina \\ Brazil \\ Lilia Aparecida Kanan \\ Post-Graduate Program in Environment and Health \\ Universidade do Planalto Catarinense \\ Av. Marechal Castelo Branco, 170. Lages. Santa Catarina \\ Brazil \\ Everley Rosane Goetz \\ Instituto de Educação Superior de Brasília \\ IESB. Quadra 613/614. Asa Sul \\ BrasíliaDistrito Federal \\ Brazil
}

\begin{abstract}
The present study investigated the processes of grieving and resilience of parents who lost their young adult children. It is an interdisciplinary, qualitative, exploratory-descriptive study. Interviews were conducted with 16 mothers and fathers and then analyzed with the content analysis technique of Bardin (2012). The participants were also asked to make drawings of their family (real versus ideal), with systematic analysis of protocols based on Campos (2007). As a result, most of the parents found that there had been significant changes in family dynamics; they feel difficulty in planning for the future and prefer to live the present moment only. The Family Drawing technique has shown that most participants have feelings of emptiness, emotional maladjustment in the environment, emotional repression to aggressiveness, satisfaction in fantasy and family breakup. As regards the parents' grieving and resilience, it was found that, in their own manner, they seek ways of coping with their loss and they are still affected by moments of intense pain.
\end{abstract}

Keywords: resilience, parents, death, young adult.

\section{Introduction}

The modern lifestyle is increasingly defined by fragile relationships marked by volatility of daily life in social networks, by social jet lag - whose villain is the clock (Roenneberg, 2012), by a massive amount of information, immediacy of results, fierce competition in the workplace, high levels of violence, a considerable increase in the number of cars on city streets and roads with a consequent increase in accidents, early onset of fatal diseases, among many other aspects that could be cited (Dumiud et al., 2017, Gorjian, Khodaveisi, Amini, Soltanian\& Reza, 2014, Motta, Bonzini, Grevendonk, Iodice, \&Bollati, 2017, Zhang, Yau, Zhang, \& Li, 2016).Understandably, all these factors, to some extent, illustrate the fact that everyone is subjected to problems of the contemporary world. Terminal illness, a serious car accident, or situations of violence, for example, which often result in early death, are conditions that, over time, started to be considered as consequences of the modern lifestyle. 
And these consequences, more often than not, lead to intense suffering, difficulties in coping with loss and restabilization, and reorganization of the family (Morton, 2018).

When a family loses a child, the process of grieving begins, and it is experienced differently by each family member. For this reason, it cannot be defined as something uniform, with a deadline to start and end. The reason is that it can last for days, months or years, and it may even never end (Parkers, 1998; Oliveira \& Lopes, 2008).

The process of grieving after a child's death is a period of great emotional stress in which it is crucial to offer a psychological intervention and preventive psychological support to parents so that they can control and elaborate their anxiety (Fernández-Alcántara, Pérez-Marfil, Catena-MartÍnez\& Cruz-Quintana, 2017, Menezes, Passareli, Drude, Santos \& Valle, 2007).

When there is such loss, i.e., something that was not designed and planned for one's child, the parents will have a narcissistic wound, which no longer represents the identification of a part of themselves present in the other (Monti, 2008). In other words: "A child's death can represent the fact that parental love could not avoid this final event, potentially challenging the quality of such love, as if it had failed. They may feel guilty because they have outlived their child" (Oliveira \& Lopes, 2008, p. 220, our translation).

The human life cycle is not always linear for all families and, faced with the death of one member, mainly a young one, the affected family will go through a grieving process, and subsequently reorganize the roles of each family member. This movement, according to Labate and Barros (2006) and Menezes, Passareli, Drude, Santos \& Valle (2007), is the free expression of feelings, whose purpose is to prevent a family crisis.The process of coping and grieving, both individually and as a group, begins after a child's death, because it is necessary to build a new family identity, in which the roles will be rearranged between people (Menezes, Passareli, Drude, Santos \& Valle, 2007, Labate\& Barros, 2006). The word resilience comes from Latin, resilio, which means to return to the normal state; in physics, it is used to refer to the ability of a material to return to its original state, even after having suffered some pressure. Resilience, in psychology, was first addressed for the purpose of studying 'overcoming' in cases of illness, traumas, grief, situations of war, social issues, immigration (Souza \&Cerveny, 2006).

Some people react and explain the facts of life in a particular way, according to their beliefs and their culture (Stefana, 2017) i.e., as if any adverse event was needed to acquire new learning experiences. Thus, a subject may react pessimistically, give great importance to a problem and become aware that their own means of overcoming it are limited, or show resilience, in an attempt to take responsibility for the problem and recognize in himself the possibilities of coping (Elmescany, 2010). Based on the points raised above, grieving processes and resilience capacity of parents who have lost young adult children were the theme of this study. We sought to make an in-depth investigation about issues relative not only to grief but also coping, in the difficult life trajectory of these parents.Another goal was the possibility of characterizing and exemplifying the most profound feelings and experiences resulting from the very abrupt and early loss of young adult children.

\section{Method}

This is an interdisciplinary, exploratory-descriptive, cross-sectional, qualitative study, based on phenomenology, because it addresses grief and its meanings, as expressed in the experience of awareness of bereaved parents. The sample was composed of 16 fathers/mothers whose young adult children, aged between 18 and 40 years old, had died. The composition of the group of participants was based on the convenience criterion and used snowball sampling. This is a non-probabilistic technique, used in social research, in which the participants of a research study recruit new participants, who in turn also recruit other new participants, until reaching the desired number of subjects; in other words, until saturation is reached, which means that the content will be repetitive among the participants' responses and, thus, will bring little significant value (Baldin\&Munhoz, 2011, Turato, 2003).

Semi-structured interviews were conducted with both parents at the same time in the participants' household. The interview script contained open questions about how the parents whose children had died experience grief and resilience: (a) How would you describe your child?; (b) How do you deal with this fact today?; (c) In what particular moment was it more difficult to cope with this new reality?; (d) What is your routine like today?; (e) How do you perceive life nowadays?; (f) Do you associate the loss of your child with any aspect of his or her lifestyle, or with some aspect of modern life?The interview script also contained closed questions about family information, socioeconomic status, and the deceased child. Later, the interviewees were asked to draw a family picture individually. The application technique consists in collecting a protocol of the real family and ideal family pictures and make a short survey (each participant was asked to draw their family in their real and ideal perceptions, referring to the family members by their names). Next, a systematic analysis was made of protocols, according to the evaluation requirements suggested by Campos (2007). 
The qualitative analysis of the answers to the open questions was based on the content analysis technique as proposed by Bardin (2012), whose content determined categories, record units, context units, codification of record units and their frequency in each category. The analysis of the drawings was based on the indicators of Campos (2007), who proposed that nine general items should be checked: (1) location on paper; (2) pressure while drawing; (3) characterization of the lines; (4) symmetry of the drawing; (5) details in the drawing; (6) movements in the drawing; (7) size of the picture; (8) use of rubber; (9) scribbling on paper.

\section{Results and Discussion}

Age of theinterviewed couples ranged between 43 and 74 years; mean age of the male participants (fathers) was 61 years and five months $(\mathrm{SD}=8.06)$. Mean age of the female participants (mothers) was 58 years and five months $(\mathrm{SD}=7.07)$. Mean length of loss was six years and six months $(\mathrm{SD}=3.04)$. Mean age of the children when they died was 26.4 ( $\mathrm{SD}=6.04$ ).Most of them, i.e., five young people, lost their lives in car accidents. Deaths caused by traffic accidents are considered to be so serious that the WHO (2015) produced a world report on road safety, which stresses that car accidents are one of the leading causes of death worldwide and the leading cause of death among young people aged between 15 and 29 years (WHO, 2015), something that was confirmed in the present study. In 2017, young people between 18 and 34 years accounted for 52\% of victims of fatal accidents in Brazil; this figure represents a 23\% increase compared to 2016 (SeguradoraLider, 2017).

The professions of the interviewees were different: three mothers were retired teachers, one was a retired businesswoman, three were retailers, and one was a homemaker. The fathers' occupations were distributed as follows: a retired driver, three entrepreneurs, a retired salesman, a doctor, a retired civil servant and a retired accountant. Only three out of the eight couples maintained a work routine after their child's death. The participants were asked whether they had had physical/mental health problems after their child's death. Eleven participants reported being diagnosed with depression, although the disease was predominant among women. The answers to the open questions we grouped into four categories, as shown below.

\subsection{Religious Issues and Memories}

One finding was that having faith in God was a way for parents to come to terms with their child's death. Although they always remembered and missed the loved one, some parents reported that there was nothing left that they could do; they had placed the situation of loss in the hands of God, as if it were God's plan. As far as memories are concerned, parents expressed feelings of sadness at the absence of their child, and the objects that they used; the pictures brought comfort and refreshed their memory.

The following examples are illustrative of these categories:

-Mother 2: [...] I miss my child so much. I walk into the living room every day and I look at his photo and kiss it. I pray, I bring flowers.

-Father 3: [...]We are a very religious family; [...] faith is what makes us stronger [...].

-Father 6: [...] without faith, this faith of ours, our belief that it was God's plan, that God allowed it, if God had not allowed it to happen, it would not have happened. I always bring up the following question: Do you believe in God? It is easy to answer that I do, but how much do you believe in Him? To the point of giving away your child's life?

-Mother 7: [...] made us hold on to our faith in God, ask for strength and courage, [...].

Farinasso and Labate conducted a study (2012) with a group of widows, and they found that faith in God can support bereaved individuals, because religion helps them to adhere to beliefs and explanations for life after death; also, religion associates God and the cause of death, in the sense that people believe that it happened because it was allowed by God.

Special meaning is assigned to the pictures and objects of the deceased child, because they are memories that keep parents and child emotionally connected after the physical separation. The role of these objects is to offer consolation and enable a symbolic physical presence, which is needed in order for life to make sense after the loss of a loved one (Picardi, 2008). Thus, to make such loss meaningful, they praise their deceased child, create spaces of memory, become the protagonists of stories of symbolic exchange with their deceased child, while constructing a path for the afterlife (Hernández \& España,2017).

Some participants clung to religion/spirituality as a possible explanation for their child's death, which they interpret as God's plan. Others reported that they became more attached to their spouse, their extended family and their other children. In addition to finding support and comfort in their faith, many parents feel supported when they bond with people who sympathize with their pain and help them maintain the ties with their deceased children (Hernández \&España, 2017). 
Although science has associated religion/spirituality with detachment, the reports analyzed in the present study are in line the findings of Farinasso and Labate (2012), who argue that spirituality and faith in God offer emotional comfort, which helps people grieve more easily.

\subsection{Desire to live for oneself and/or for the loved ones that are still alive}

This category reflects the parents' desire to experience the present time, to seek a daily meaning in the "here and now". The interviewed parents explicitly reported that they sought motivation to continue living. Whether willingly or by external motivations (other children, grandchildren, for example), moving on with their lives is a goal pursued by almost all interviewed parents. Only a father and a mother verbally stated that they no longer wished to live. All answers about motivation, whether internal or external, are indicative of their resilience capacity. Some of the most representative accounts in this category are shown below.

-Father 1: [...] I think I want to live, I want to see my grandchildren grow [...] while I'm normal (health) all I think about is to live $[\ldots]$.

-Father 5: [...] I live the moment, [...].

-Father 8: [...] I do not think about the future, about tomorrow... we are alive today, but tomorrow, I'm not sure, I don't worry any longer... I used to aim at this and that... let us live the present moment[...].

-Mother 6: see the girls graduate and well...and retire, have peace and quiet, if it's God's plan, move on with our lives, right!

-Mother 7: I believe in the future of my children, you know; I think that now we have to pray, because life goes on in spite of it all...

The reports of the participants show that their attempt to overcome their loss in the course of life is influenced by protective and motivational factors mainly relative to members of the family. There are reports of movements whose aim is to emotionally cope with the situation, something that helps them reconstruct life and reorganize concepts, beliefs and values (Santiago, Souza, Lacerda\& Hairstyle, 2008). There is a description of behaviors and reasons for behaviors aimed at grieving, which may be an opportunity for symbolic elaboration in the face of suffering, recovery and (re)construction of new networks of meanings to the lived experience (Elmescany, 2010).

\subsection{Life became meaningless and/or perceived as unfair}

Six parents reported that they felt life was meaningless or that lifewas unfair to them. This category represents the way through which parents realize and feel the loss of their child. The following statements exemplify this category:

-Mother 2: [...] life became difficult after he died, we feel like orphans, children are supposed to bury their parents, but parents are not supposed to bury their children, [...].

-Father 3: Everything is very complicated, because when we lose a son, we lose a piece of ourselves and it's not easy to feel like a whole person again, there is always a void...

-Father 5: there's no meaning to life after that, [...]

-Father 7: [...] for me it was a loss that... I lost my father about 30 years ago in the same type of event, only now with my child it feels a thousand times worse.

These parents clearly show difficulty in coping with their loss and separation. Facing the loss of a child is not something simple, because there are extremely significant ties and close relationships between parents and children (Rangel, 2012). These parents show a certain sense of failure by the fact that they continue to live after their child's death; these are feelings that foster their perception of injustice as a result of life's circumstances (Viorst, 1998). The circumstances of death shall determine the situations and feelings that make the parents analyze what has or has not been done, thus making them have feelings of guilt that cannot be circumvented, but only mitigated (Rangel, 2012).

\subsection{Coping with the loss}

Some parents reported that, in their daily lives, they attempt to learn how to cope with loss and grief and try to overcome them. By doing so, they mitigate the feeling of anger in order to try and accept the fact. After all, while one cannot change the fact that a loved one has died or change the circumstances of their death, one can change the way they try to come to terms with such loss (Stroebe, Schut\&Boerner, 2017).

The expressions below illustrate elements of this category.

-Mother 1: [...] there are days when I try to accept, there are days when I try to understand, [...]. -Father 4: [...] She won't come back, we have to keep going, but once in a while my heart sinks! -Mother 4: [...] but we realized that we can't bring her back, we have to continue living, [...].

The reports of the participants indicated the use of a defense mechanism known as 'Displacement', which, according to Sadock and Sadock (2007), consists in shifting an emotion or impulse from a thought or object towards a similar one to 
reduce disturbance in an individual. In addition, the 'Control' mechanism is also used, in which someone attempts to control events in the environment to minimize their anxiety and resolve inner conflicts.According to Kübler-Ross (2005), grieving parents react to their child's death in five stages: 1) shock and denial; 2) anger; 3) bargaining; 4) depression; 5) acceptance. In the present study, most fathers are at the stage of acceptance, but some mothers still feel depression. Being at the stage of acceptance can be attributed to time elapsed after their loss and represents a factor that commonly assists in grieving and resilience.

\subsection{Positive qualities of their children}

The parents could talk about their perception of their deceased son/daughter. Their statements showed that the most of them seek to keep good memories.Such perceptions include issues relative to character, personality, manners, friendliness and lovingness.

-Father 1: he was a responsible young man, he started working at an early age, he never caused any problems, he started a family..., he was a good son [...].

-Father 2: he was very sweet, very polite, honest, friendly, [...]

-Mother 3: My God, he meant everything to me; a loving, polite, hard-working son; he always did things right.

-Mother 4: a very happy, dynamic, caring person; he got along well with everyone, with his family, with his siblings....

-Mother 5: wonderful, helpful, sweet, intelligent, organized; she had all the best qualities of a girl her age; this is what I see, what I saw her in her.

-Mother 6: happy, responsible girl; in our eyes, children are perfect anyway, but M. was special; there was something different about her; she made friends easily; she was spontaneous; she sometimes behaved as a daughter, sometimes as a mother; she was special, she really made a difference.

-Mother 7: a beloved son, affectionate, a good friend, a good company at every moment, he was more than only my child; he was my life, he was a piece of me.

In a study conducted by Morelli, Scorsolini-Comin\& Santos (2013) with a couple who had lost their child, only the mother mentioned positive qualities of her child while the father reported negative aspects about their personality. The author concluded that, understandably, mothers may idealize their children, i.e., highlight only positive qualities, e.g., about their beauty, attractiveness, etc.

Fifteen out of the 16 interviewed parents expressed only positive qualities. These data indicate idealization as a defense mechanism of bereaved parents, who do not mention negative aspects of their deceased child's behavior or personality (Morelli, Scorsolini-Comin\& Santos, 2013).

The analysis of parents' statements in this category suggests that keeping good memories shows their good inner capacity to cope with loss. It can be inferred that these parents move on with their lives to cope with mourning, supported by their capacity for resilience.

\subsection{Family Drawing}

The Family Drawing technique showed that the participants seem to usually have feelings of emptiness, of some emotional maladjustment, repressed aggressiveness, satisfaction in fantasy and family breakup. These feelings are possibly caused by the loss of their children. Many of these symptoms are part of a depression syndrome which can still persist in those parents, as a result of their significant loss.

\section{Final remarks}

Death is considered to have a universal and ordinary nature, and it represents an extraordinary experience in the life of the bereaved (Maddrell\&Sidaway, 2016). Studies on death and dying and the implications that arise as a result of this fact for the bereaved, whether they are children, spouses or parents, are being carried out by several authors (Bittencourt, Quintana \& Velho, 2011, Corr, Corr, \&Doka 2018, Kübler-Ross, 2005, Luizaga\& Gottlieb, 2013). However, their meanings are specific and they lie within some cultural frameworks (Hernández \&España, 2017).Often, there are significant changes in the family dynamics of bereaved parents, for example, difficulty in devising or making plans for the future. They prefer to live the present moment without focusing on everyday concerns and without feeling anxious about what has not happened or what they cannot control. It appears that there was a paradigm shift for the bereaved parents, because what used to be important before they lost their child was no longer relevant, for example, acquiring and accumulating material goods, having a high income, etc.Despite the emotional difficulties in grieving after the loss of their child, these parents seek, in their own manner, ways of coping with this new reality.

Behaviors that represent this coping attitude include resorting to faith/religion, emphasizing the positive qualities of their children, keeping objects that symbolize the image of their children, appreciating the present, being more affectionate and caring to their other children and grandchildren and resignifying family values. 
Parental loss of a child can be experienced as loss of an important part of oneself, and this was confirmed in the present study. The reports of the participants suggest that there are personal attempts of coping that show how important such loss is to the parents' own personal history, which, in turn, is composed of their children's history (Hernández \&España, 2017).Thus, parents want this part of their history, i.e., their children, to always reflect positive qualities, because they can feel assured that they provided good advice and upbringing during the time which they spent together. In a way, this is something that helps them grieve, because if they believe that their child was a good person and is in heaven, they will believe that they fulfilled their role as parents until the time of their child's death. The reports clearly show that the parents feel frustrated because their children died too soon and hence the latter's life will have noncontinuity and non-achievement. This confirms the reversal of the expected logic of the vital cycle, i.e., parents should die before their children. This does not translate into overcoming the loss of their child, but into seeking less painful ways to cope with it.No consistent differences were found in the way parents feel and perceive the loss of their child; rather, feelings and perceptionswere similar. The fathers found it more difficult to speak about the loss than the mothers, something that can be explained by gender-related cultural aspects. There are differences and similarities in the way people deal with death and grieving, something that is related to collective and cultural characteristics of societies, which have their own collective language to express emotions (Stefana, 2017).

Finally, it is noteworthy that further research should be conducted with a larger number of participants to produce representative results and allow inferences about the population with similar characteristics. Although it is difficult to find participants because the issue is delicate and painful to parents, research can be used as a strategy to support them while coping with their loss, because the couple can readdress this topic, discuss their experiences, gain awareness of changes in their roles and in the family, and approach issues that may have been avoided or repressed over time.

\section{References}

Baldin, N. \& Munhoz, E. (2011, novembro). Snowball (Bola de neve): uma técnica metodológica para pesquisa em educação ambiental comunitária. Anais do X congressonacional de Educação -Educere. Curitiba, PR, Brasil. Available http://educere.bruc.com.br/CD2011/pdf/4398_2342.pdf

Bardin, L. (2012). Análise de Conteúdo. Rio de Janeiro: Editora Edições 70.

Becoña, E. (2006). Resiliencia: definición, características y utilidad del concepto. Revista de Psicopatología y Psicología Clínica 11 (3), 125-146 .Avaiable in http://revistas.uned.es/index.php/RPPC/article/view/4024.

Bittencourt, A.L.T.; Quintana, A.M. \& Velho, M. T. A. C. (2011). A perda do filho: luto e doação de órgãos. Estudos de Psicologia. 28(4), 435-442. Available in http://dx.doi.org/10.1590/S0103-166X2011000400004.

Campos, D. M. S. (2007). O teste do desenho como um instrumento de diagnóstico da personalidade. Petrópolis: Vozes.

Corr, C. A., Corr, D. M., \& Doka, K. J. (2018). Death \& dying, life \& living. Boston: Cengage Learning.

Dumuid, D., Olds, T., Lewis, L. K., Martin-Fernández, J. A., Katzmarzyk, P. T., Barreira, T., ... \&Kuriyan, R. (2017). Health-related quality of life and lifestyle behavior clusters in school-aged children from 12 countries. The Journal of pediatrics, 183, 178-183. Available in https://doi.org/10.1016/j.jpeds.2016.12.048

Elmescany, E. N. M. (2010). A arte na promoção da resilência: um caminho de intervenção terapêutica ocupacional na atenção oncológica. Revista do NUFEN, 2(2), 21-41. Available in http://pepsic.bvsalud.org/scielo.php?script=sci_arttext\&pid=S2175-25912010000200003\&lng=pt\&tlng=pt.

Farinasso, A. L. C. \&Labate, R. C. (2012). Luto, religiosidade e espiritualidade: um estudo clínico-qualitativo com viúvas idosasRevista Eletronica de Enfermagem, 14(3), 588-95. Available in http://www.fen.ufg.br/revista/v14/n3/v14n3a15.htm.

Fernández-Alcántara, M., Pérez-Marfil, M. N., Catena-Martínez, A., \& Cruz-Quintana, F. (2017). Grieving and loss processes: latest findings and complexities/Actualidad y complejidad de los procesos de duelo y pérdida. Estudios de Psicología, 38(3), 561-581. DOI: 10.1080/02109395.2017.1328210

Gorjian, S., Khodaveisi, M., Amini, R., Soltanian, A. R., \& Reza, P. F. (2014). Drivers' lifestyle as human factor in the occurrence of traffic accidents in Hamadan. Scientific Journal of Hamadan Nursing \& Midwifery, (23), 33. Available in http://nmj.umsha.ac.ir/browse.php?a_id=1311\&sid=1\&slc_lang=en

Hernández, A. M. G., \&España, T. I. C. (2017). Narrativas y continuidad de vínculos en padres que perdieronhijos. Majorensis:Revista Electrónica de Ciencia y Tecnología, (13), 118-125. Available in https://dialnet.unirioja.es/servlet/articulo?codigo $=6357594$

Kubler-Ross, E. (2005). Sobre a morte e o morrer. São Paulo: Martins Fontes.

Labate, R. C. \& Barros, G. C. (2006). Uma possibilidade de escuta a uma família enlutada: ressignificando a experiência de perda. Revista da SPAGESP - Sociedade de Psicoterapias Analíticas Grupais do Estado de São Paulo, Jan.-Jun. 7 (1), 50-57. Available in http://pepsic.bvsalud.org/pdf/rspagesp/v7n1/v7n1a07.pdf 
Luizaga, C. T. M. \& Gotlieb, S. L. D. (2013). Mortalidade masculina em três capitais brasileiras, 1997 a 2007 . Revista Brasileira de Epidemiologia, 16(1), 87-99. Available in http://dx.doi.org/10.1590/S1415-790X2013000100009

Maddrell, A. \&Sidaway, J. D. (2016).Deathscapes: Spaces for death, dying, mourning and remembrance. London: Routledge.

Menezes, C. N. B., Passareli, P. M., Drude, F. S., Santos, M. A., \& Valle, E. R. M. (2007). Câncer infantil: organização familiar e doença. Revista Subjetividades, 7(1), 191-210. Available in

$\mathrm{http} / / /$ periodicos.unifor.br/rmes/article/view/1579

Monti, M. R. (2008). Contrato narcisista e clínica do vazio. Revista Latino-americana dePsicopatologia Fundamenta.l, 11 (2), 239-253. Available in http://www.scielo.br/pdf/rlpf/v11n2/a06v11n2.pdf

Morelli, A. B., Scorsolini-Comin, F. \& Santos, M. A. (2014). Elementos para uma Intervenção em Aconselhamento Psicológico com Pais Enlutados. Psico,45(4), 434-444. Available in http://revistaseletronicas.pucrs.br/ojs/index.php/revistapsico /article/viewFile/14640/12470

Morton, D. P. (2018). Combining lifestyle medicine and positive psychology to improve mental health and emotional well-being. American Journal of Lifestyle Medicine, 12(5), 370-374. https://doi.org/10.1177/1559827618766482

Motta, V., Bonzini, M., Grevendonk, L., Iodice, S., \&Bollati, V. (2017). Epigenetics applied to epidemiology: investigating environmental factors and lifestyle influence on human health. La Medicina del lavoro, 108(1), 10-23. DOI: $10.23749 / \mathrm{mdl} . v 108 \mathrm{i} 1.6072$

Oliveira, J. B. A. \& Lopes, R. G. C. (2008). O processo de luto no idoso por morte de cônjuge ou filho. Psicologia em Estudo, 3(2), 2217-221. Available in http://www.scielo.br/pdf/pe/v13n2/a03v13n2.pdf

Omar, A., Paris, L., Delgado, H. U., Silva Júnior, S. H. A. \& Souza, M. A. (2011). Un modelo explicativo de resiliencia en jovenes y adolescentes. Psicologia em Estudo, 16, (2), 269-277. Available in http://pt.scribd.com/doc/188617151/Un-Modelo-Explicativo-de-Resiliencia-en-Jovenes-y-Adolescentes\#scribd

Organização Mundial de Saúde-OMS. (2015). Global status report on road safety. Geneva, World Health Organization. Available in http://www.who.int/violence_injury_prevention/road_safety_status/2015/GSRRS2015_Summary_EN_final2.pdf?ua=1

Parkers, C. M. (1998). Luto: estudos sobre a perda na vida adulta. São Paulo: Summus Editorial.

Piccardi, T. (2008). Relatos de pais enlutados: a dor posta em discurso. Revista Alpha, 9 (9), 129-137. Available in http://alpha.unipam.edu.br/documents/18125/22328/relatos.pdf

Rangel, A. P. F. N. (2012). Dilemas éticos na morte de filhos. O Mundo da Saúde, 36(1), 11-26.

Roenneberg, T. (2012). Internal time: Chronotypes, social jet lag, and why you're so tired. Harvard University Press. London, England.

Sadock, V.A. \& Sadock, B. J. (2007). Compêndio de psiquiatria: ciência do comportamento e psiquiatria clínica. Porto Alegre: Artmed.

Santiago, E.S., Souza, E. O. A., Lacerda, M. C. M. \& Penteado, P. Q. L. (2008). Da perda à superação: a vivência do conceito de resiliência em mulheres que perderam seus companheiros. Omnia Saúde, 5 (2), 68-91. Available in http://www.fai.com.br/portal/ojs/index.php/omniasaude/article/viewFile/258/pdf

Seguradora Lider. (2017). Relatório Anual. Available in https://www.seguradoralider.com.br/Documents/RelatorioAnual/Relatorio-Anual-Seguradora\%20Lider_2017.pdf

Souza,M. T. S. \&Cerveny, C. M. O. (2006). Resiliência psicológica: revisão da literatura e análise da produção científica. InteramericanJounal of Psycology, 40 (1), 119-126. Available in http://www.redalyc.org/articulo.oa?id=28440113

Stefana, A. (2017). Mourning the death of a foreign child. The Indian Journal of Pediatrics, 84(3), 245-245. Available in https://doi.org/10.1007/s12098-016-2264-2

Stroebe, M., Schut, H. \& Boerner, K. (2017) Models of coping with bereavement: an updated overview. Estudios de Psicología, 38 (3), 582-607, DOI: 10.1080/02109395.2017.1340055

Turato, E. (2003). Tratado de metodologia da pesquisa clínico-qualitativa. Petrópolis, RJ: Vozes.

Viorst, J. (1998). Perdas necessárias. São Paulo: Melhoramentos.

World Health Organization (WHO). (1998). Health promotion glossary. Genèva. Switzerland. Available in http://www.bvsde.ops-oms.org/bvsast/e/fulltext/relcosta/anexo7.html

Zhang, G., Yau, K. K., Zhang, X., \& Li, Y. (2016). Traffic accidents involving fatigue driving and their extent of casualties. Accident Analysis \& Prevention, 87, 34-42. Available in https://doi.org/10.1016/j.aap.2015.10.033 